\title{
Double Antibody EIA of Cortisol using Peroxidase as Label
}

\author{
Adil Mohammed Hashim, F. M. Karim and A.W. R. Hamad \\ Ministry of Science and Technology, Baghdad-Iraq
}

\begin{abstract}
An enzyme immunoassay (EIA) technique for plasma cortisol was Established by using cortisol-3 (carboxymethyl)oxime covalently linked To the horseradish peroxidase as the label antibody raised in the rabbits against cortisol -3- (carboxymethyly.)oxide -bovine serum Albumin was used as the first antibody .sheep ant-rabbit gamma-globulin Serum with \& percent polyethyleneglycol were used to separate Antibody-bound and free cortisol. The enzyme activity of the bound fraction was measured with ortho-Phenylenediamine as substrate. the procedure performed at room Temperature was evaluated though sensitivity which was found to be 50Pg/tube. The correlation coefficient between our enzyme immunoassay Technique for determination of plasma cortisol was 97 percent.
\end{abstract}

Keywords: Double Antibody, EIA, Peroxidase, cortisol.

\section{Introduction}

Determination of circulating blood cortisol concentrations is hight Useful in assessing adrenocortical function (1) radioimmunossay (RIA)Is widely used for determination of pictogram quantities of cortisol in blood, but this method involves radiation hazards, and the isotopes used have short shelf - lives and are expensive (2) .RecenlyenzymeImmunoassays (EIA) of cortisol have been delveloped and applied to the measurement of plasma cortisol based 0 n the perocedure of comoglio et al(4).We have delveloped an enzyme immunoassay for cortisol which is Slightly less sensitive than radio-immunoassay using horseradish peroxidase as the enzyme to label the cortisol since peroxidase was available commercially in highly purified stable form and retains activity after covalent coupling. The purpose of this research is to produce cortisol assay that would be more sensitive ,stable and accurate also to be précis assay for a suitable determination of plamsma cortisol.

\section{Materials and Methods}

Cortisol, bovine serum (BSA)iso-butylisoichioroformate, horseradishPeroxidase (HRP) (MRP,EC.1.11.17)were purchased from sigma chemical co ltd.Polyethylene glycol 6000 was purchead from (E.Merck.AGpoole Dorset U.K) tri $-\mathrm{n}$ - butyl amine dioxane .(BDH.ChemicalLTd .poole Dorset U.K) ,completebFreundsAdjuvant .(DIFCOlaboratories,Detroit Michigan ).Sephadex G-100 (pharmacia fine chemical,Sweden). Orthophenylenediamine OPD (AldirichChemicals Co ltd.england.

\section{Cortisol standard;}

was stored as $1 \mathrm{mg} / \mathrm{ml}$ stock solution in ethanol at 20C,The working standard solutions 1.17 to ug $61.7 \mathrm{ug} / 100 \mathrm{ml}$ were prepared by dilution with free serum of cortisol and stored at 4 C.the stability of standards were studied for six months.

\section{Buffers}

Phosphate buffered saline PH 7.4 Dissolve $(0.2 \mathrm{~g})$ of sodium hydrogen phosphate $(\mathrm{NaH} 2 \mathrm{po} 4.12 \mathrm{H} 2 \mathrm{O}) 2.68 \mathrm{~g}$ of sodium hydrogen phosphate $(\mathrm{Na} 2 \mathrm{pH} 4.12 \mathrm{H} 2 \mathrm{O})$ and $7.72 \mathrm{~g}$ of sodium chloride in liter of distilled water , containing $0.1 \%$ bovine serum albumin .

Substrate solution: dissolve $30 \mathrm{mg}$ of o-phenylenediamine in $100 \mathrm{ml}$ of substrate buffer : $30 \mathrm{w} / \mathrm{v}$ hydrogen peroxide (20ul) was added after dissolution of o-phenylenediamine was complete . cortisol 3carboxymethyloxime (C-3 CMO ) was synthesized according to pourfarzanahetal(5) . conjugation of cortisol 3-carboxymethyloxime to horseradish peroxidase .

A conjugate of horseradish peroxidase cortisol can be prepared by the mixed anhydride technique as modification(6,7). Cortisol -3- carboxymethyloxime (11,6mg 0,02 m mole ) was dissolved in $0.8 \mathrm{ml}$ dry dioxin to which $(0.014 \mathrm{ml}, 0.5 \mathrm{~m} \mathrm{~mol})$ tri-n-butylamine was added and the solution was cooled with $0.007 \mathrm{ml}(0.5 \mathrm{~m}$ mole ) of iso- butylchloroformate The reaction was allowed to proceed at the cold for $30 \mathrm{~min}$. The mixture was added in one portion to cold solution of $18.1 \mathrm{mg}$ of HRP $(0.0004 \mathrm{~m}$ mole $), 0,8 \mathrm{ml}$ of water , $(0,6 \mathrm{ml})$ of dioxin 
and $(0,03 \mathrm{ml}$ of $1 \mathrm{~mol} / \mathrm{L}) \mathrm{NaOH}$. Stirring and cooling were continued for 4 hours with the $\mathrm{PH}$ at 8.5 throughout the reaction .

The solution was dialyzed against ionized water for 3 days and then it was applied to a sephadex G-25 $\mathrm{M}$ column and eluted with $0.15 \mathrm{M}$ saline containing $0.1 \%$ sodium azide . the fractions containing enzyme activity were collected and pooled, BSA was added to give $1 \mathrm{~g} / 1$ solution . the cortisol -3-CMOS-horseradish peroxides conjugate (enzyme label) was serially diluted from 1:200 and $100 \mathrm{ul}$ of each dilution reacted with 2 $\mathrm{ml} 0$-phenylene diamine $(0.6 \mathrm{mg}, 2.8 \mathrm{~mm})$ and hydrogen peroxide $(0.6 \%)$ for $2 \mathrm{hrs}$. in the bark at room temperature . reaction was terminated by the addition of $4 \mathrm{~N}$ sulphuric acid $(0.2 \mathrm{ml})$.

The optical density of the supernatant was measured at $492 \mathrm{~nm}$, and the resultant graph is shown in fig (1). An approximate dilution of the enzyme label was selected on the linear portion of the graph.

\section{Anti-serum preparation :}

The immunogem, cortisol -3- (0-carboxymethyl) oxim coupled to bovine serum albumin was prepared by standard procedure (8) . six white rabbits were immunized with a suspension of $0.6 \mathrm{mg}$ the immunogen in an emulison (2:1 by vol ) of freunnd s complete adjuvant and isotonic saline . one $\mathrm{ml}$ of the emulsion was injected supcutaneously in to each rabbit at multiple sites . Immunization was repeated four times and then rappits bled, 10 days after the last immunization . four rabbit had produced antisera with titer greater than $1 / 6000$ and found to be highly specific (9).

\section{Enzyme immunoassay procedure :}

In labeled $12 \times 75 \mathrm{~mm}$ glass tubes, place $100 \mathrm{ul}$ of plasma or serum samples and standards and $400 \mathrm{ul}$ of assay buffer, which were mixed briefly and heated for $30 \mathrm{~min}$ in a water bath at $60 \mathrm{c}$. the mixture was cooled and mixed with 100 of enzyme labeled cortisol and $200 \mathrm{ul}$ of anti-cortisol serum.

The solution was then incubated at $4 \mathrm{C}$ for overnight ,one $\mathrm{ml}$ of sheep anti -rabbit gamma -globulin solution containing $8 \%$ polyethylene glycol was added and centrifuged at $2000 \mathrm{~g}$ at for $15 \mathrm{~min}$.Decantation of supernatant and substrate buffer was added as described previously.

\section{Antibody Concentration:}

The peroxidase-cortisol fraction was dilution to 1:1000 .Labeled cortisol $(0.1 \mathrm{ml})$ and incubated over night at $4 \mathrm{C}$ with anti-cortisol serum (0.2)at serial dilution in phosphate buffer PH 7.4 The dilution curve result are shown in figure (2) and indicate that the cortisol label enzyme is almost completely reacted with antibody.

\section{Optimmumorthophenylenediamin (OPD) concentration :}

Cortisol -3-CMO- HRP was assayed in $0.1 \mathrm{ml}$ volume and $0.2 \mathrm{ml}$ of anti-cortisol serum with $2 \mathrm{ml}$ substrate buffer containing 0.1 to $0.7 \mathrm{mg} / \mathrm{ml}$ OPD. The absorbance's (492nm) of the reaction were read out after $2 \mathrm{hrs}$. fig (3).

\section{Analytical variables:}

Sensitivity:

Sensitivity of the standard curve is defined according to the criteria of Kaiser and specker (10) as the least amount distinguishable from zero at the $95 \%$ confidence level, the minimal amount of cortisol detected was $0.05 \mathrm{ng}$ per assay tube .

\section{Precision:}

Intra-and-inter-assay variations were assessed by assays on the serum samples with high medium and low cortisol concentration the three levels of cortisol are 30.13.2, $6.8 \mathrm{ug} / \mathrm{dl}$ of cortisol respectively the intraassay coefficient of variations (c.v) of 10 samples were $10.6,8.7$ and $6.2 \%$ rwspectively . the values for interassay (c.v) were $10.8 \%$ (mean $32.3 \mathrm{ug} / \mathrm{dl}, \mathrm{n}=10$ ) $8.4 \%$ ( mean $12.8 \mathrm{ug} / \mathrm{dl} \mathrm{n}=10$ ) and $8.1 \%$ (mean $12.8 \mathrm{ug} / \mathrm{dl}$ $\mathrm{n}=10$ ) and $8.1 \%$ (mean $6.5 \mathrm{ug} / \mathrm{dl} \mathrm{n}=10$ ) respectively.

\section{Accuracy:}

Recovery experiments were performed by measuring the levels of cortisol present in $1 \mathrm{ml}$ of plasma which were added increasing was closely approximate the expected values .

\section{Specificity:}

Table (2) shows almost no variable in comparing the plasma cortisol with other materials structurally related steroids. Specificities obtained from EIA and RIA are similarly influenced. The degree of specificity provided by our method is sufficient for the determination of plasma cortisol because its concentration is much higher than at other steroids in plasma (2). 


\section{Comparison between radioimmunoassay and enzyme immunoassay}

To assess the reliability of the test by EIA of cortisol level in 41 serum samples were Nearly similar to those results which were obtained by RIA fig. (4) There was nearly similar to those results which were obtained determined by both Techniques.

\section{Discussion}

The development of hormones and drugs has greatly Contributed to the basic and clinical studies in the field of endocrinology And reproduction (3).RIA, however, has some disadvantages; themethod is generally expensive and hazardous, and the radioactivity of the isotope cannot be marinated for along time.EIA, one of the most widely applied non-isotopic immunoassay Because of the absence of radiation hazards often encountered in RIA the Advantages of enzyme immunoassay were already stated by wisdom(12), Comoglio et al (4) prepared cortisol 21 - hemisucctanate B-glactosidaseConjate as enzyme - labeled material and cortisol -21hemi-Succinct- BSA, conjugate as an immunogenic . the sensitivity of their method was 100-150 pg.

In the present study cortisol enzyme immunoassay was carried out by combination coruisol-3 carboxymethyloxime- horseradish peroxides conjugate and cortisol -3- CMO-RSA conjugate by mixed anhydride method, the sensitivity of their present method was $50 \mathrm{pg}$. The higher sensitivity achieved in the method may be due to high purity of cortisol -enzyme complex and also due to high specificity of anti-cortisol serum. To examine the clinical reliability of the EIA, plasma cortisol level estimated by enzyme immunoassay and RIA method as showing in fig (4).The results obtained upon application of EIA were highly correlated(correlation coefficient, $\mathrm{r}=0.970$ ). with the values obtained by Rather proposed method is sufficiently sensitive, reproducible, simple And accurate for use in routine measurement of serum cortisol and is applicable to automation.

\section{References}

[1]. Lowell foster,B. and Ralph dunn, T . Clin. Chem . 20:365, (1974)

[2]. Yoshiharo, K; kiyoshi, M. T. Noriko and Fukuko W. steroid . 34:2551,(1979)

[3]. Nokao, T.; Tamamura, F.TSUNODA and kowat . j. steroid . 38:111, (1981).

[4]. Comoglic, S. and celada, F.j. immunol . Methods 10:161,(1979).

[5]. Pourfarzanah, M.; Wite, G.W.; landon, j . and Smith , D.S. clin. Chem . 26(1980).

[6]. Erlanger, B.f. and Beiser, S.M borek, "In methods in in immunochemistry" Williams and M. W chase, Eds Academic press, Newyourk, NY,P.149: (1967).

[7]. Thua, M. o. ; kari , o.j and Guldo, D.Gclin . chem . 25:716, (1979)

[8]. Erlanger, B.F, ;borek , F. B. ;Beiser, S.M. ;and Lieberman, S.M j.Biol Chem.228:713,(1957).

[9]. Schoneshofer, M. ; Weber, B. J. steroid Biochem 18:65,(1983).

[10]. Kaiser. H; Berwertung ,H. S . and vergleich, V.A. Anal chem. 149:46(1956).

[11]. Kominami, G.; fujisaka, I.; yamauchi, A. and Kano, M., Clinica chemical Acta, $103: 381,(1980)$.

[12]. Wisdom. G.B ., chin . chem .22:1242,(1976).

[13]. Stulnig et al. (2004),11 $\beta$-Hydroxysteroid Dehydrogenase Type 1 in Obesity and Type 2 Diabertes. Diabetologia 47, 1-11.

[14]. Nicholas F. LaRusso (2008), The AGA Institute: A Professional Society With a Social Conscience, vol. 135, Issue 6, pages e12-e13.

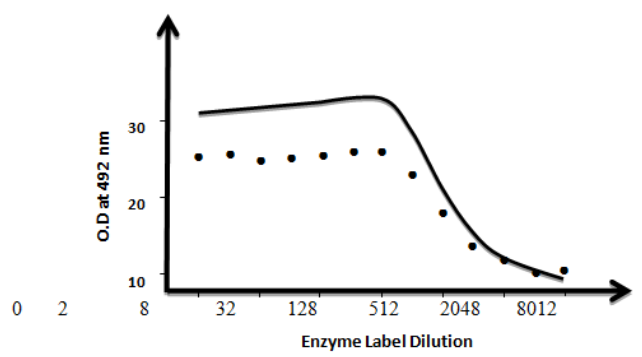

Fig. ( 1 ) : Serial dilution of cortisol -3- ( carboxymenthyl ) oxime - horseradish peroxidase against a standard concentration of substrate [ o phenylenediamine $(2.8 \mathrm{mM})$ hydrogen peroxide $(0.06 \%)$ ]

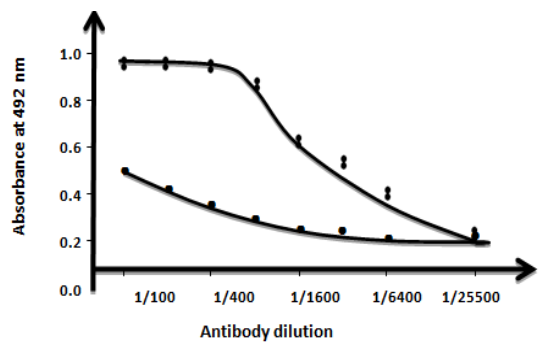

Fig. ( 2 ) : Effect of different concemmtion of anti-cortisol on final absorbance in the present ( $)$ and absence of cortisol ( ) 


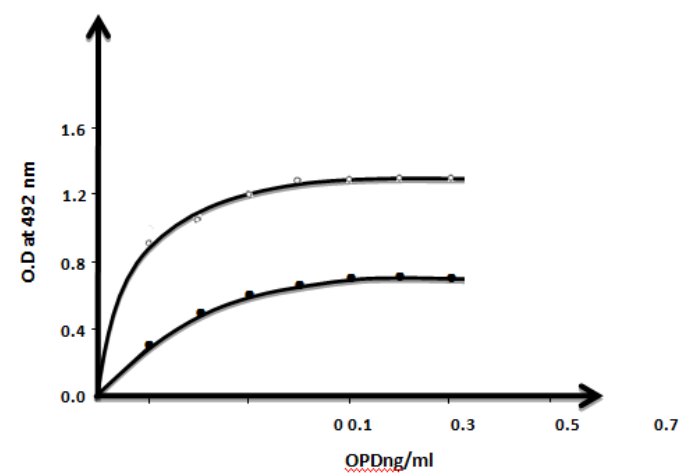

Fig. ( 3 ) : Effect of substrate concentration on the peroxidase reaction in the presence ( ) and absence of cortisol ( )

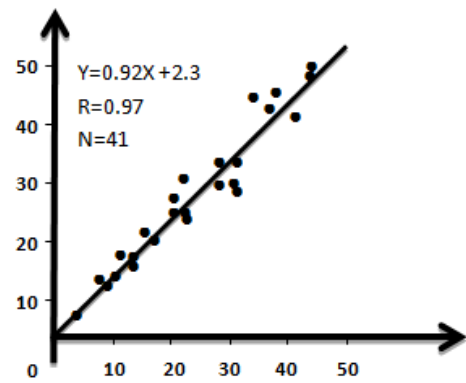

Fig. ( 4 ) : Correlation between cortisol levels in plasma measured by enzyme immunoassay and radioimmunoassay.

Table (1) Recovery Test

\begin{tabular}{|c|c|c|c|}
\hline $\begin{array}{c}\text { Cortisol Quantity } \\
\text { Ug/dl }\end{array}$ & $\begin{array}{c}\text { Expected Cortisol Quantity } \\
\text { Ug/dl }\end{array}$ & $\begin{array}{c}\text { Obtained Cortisol Quantity } \\
\text { Ug/dl }\end{array}$ & Recovery Ratio \% \\
\hline 0 & --- & 10.2 & --- \\
\hline 2 & 12.2 & 11.6 & 95.5 \\
\hline 4.1 & 14.3 & 14.5 & 101.3 \\
\hline 8.2 & 18.4 & 17.8 & 96.7 \\
\hline 12.5 & 22.7 & 22.3 & 98.2 \\
\hline 15 & 25.2 & 24.5 & 97.2 \\
\hline 18.2 & 28.4 & 27.5 & 96.8 \\
\hline 20 & 30.2 & 31.1 & 102.8 \\
\hline 25 & 35.2 & 33.7 & 95.7 \\
\hline
\end{tabular}

Table (2) Cross Reactivity for Corticol-3- CMO-BSA with some of SteroidalCompounds

\begin{tabular}{|c|c|}
\hline Cross Reactivity \% & Steroidal Compounds \\
\hline 2.2 & Cortisone \\
\hline 10 & 11-Deoxy Cortisol \\
\hline 3.1 & Hydrocortisone-21-hemisuccinate \\
\hline 31.2 & Prednisolone \\
\hline 0.1 & 11a-hydroxyl progesterone \\
\hline 5 & 21-Deoxy cortisone \\
\hline 0.1 & 17a-hydroxyl progesterone \\
\hline 0.1 & Testosterone \\
\hline 0.7 & Deoxycorticosterone \\
\hline 5.6 & Progesterone \\
\hline 0.5 & Dexamethasone \\
\hline 0.5 & Corticosterone \\
\hline 0.5 & Tetra hydra cortisol \\
\hline
\end{tabular}

